\title{
Physiotherapeutic treatment Schedule for chronic low back pain: influence on pain, quality of life and functional capacity
}

\author{
Programa de tratamento fisioterapêutico para dor lombar crônica: influência sobre a dor, \\ qualidade de vida e capacidade funcional
}

Mariana Regina Arins ${ }^{1}$, Nicole Murara ${ }^{1}$, Xayani Bottamedi ${ }^{1}$, Juliano dos Santos Ramos ${ }^{1}$, Simone Suzuki Woellner ${ }^{2}$, Antonio Vinicius Soares $^{1}$

DOI 10.5935/1806-0013.20160069

\section{ABSTRACT}

BACKGROUND AND OBJECTIVES: Low back pain is a public health problem affecting population regardless of social and economic class. Segmental stabilization is a kinesiotherapeutic technique being considered treatment option for this disorder. Primary objective of this study was to evaluate the effects of a treatment schedule for low back pain based on segmental stability principles. The secondary objective was to propose and adaptation of Nottingham Health Profile, which is a tool to evaluate quality of life.

METHODS: This is a pre-experimental study involving 25 chronic low back pain patients of both genders, mean age of 50.5 years. The study consisted of 16 sessions of a segmental stabilization exercises program, carried out twice a week during six months. Measurement tools were: visual analog scale, RolandMorris questionnaire and two versions of Nottingham Health Profile, namely translated and modified.

RESULTS: At treatment completion, all patients had significant improvement in variables controlled by the study. Modified Nottingham Health Profile version had strong and significant correlation with the translated version ( $\mathrm{r} 0.88$ ) and with functional incapacity level evaluated by Roland Morris questionnaire ( $\mathrm{r} 0.85$ ).

CONCLUSION: Proposed treatment schedule was beneficial for patients involved in the study. Modified version of Nottingham Health Profile may be used to evaluate quality of life perception especially of chronic low back pain patients.

Keywords: Chronic low back pain, Functional capacity, Physiotherapy, Quality of life.

\footnotetext{
1. Faculdade Guilherme Guimbala, Departamento de Fisioterapia, Joinville, SC, Brasil. 2. Prefeitura Municipal de Joinville, Departamento de Fisioterapia, Joinville, SC, Brasil.

Submitted in February 21, 2016.

Accepted for publication in August 09, 2016.

Conflict of interests: none - Sponsoring sources: none.

Correspondence to:

Rua São José, 490, Centro

89202-010 Joinville, SC, Brasil.

E-mail: provinicius.soares@gmail.com

(C) Sociedade Brasileira para o Estudo da Dor
}

\section{RESUMO}

JUSTIFICATIVA E OBJETIVOS: A dor lombar é um problema de saúde pública que afeta a populaçáo independentemente da sua classe social e econômica, indiscriminadamente. A estabilização segmentar é uma técnica cinesioterapêutica que tem se destacado como opçáo de tratamento para esse distúrbio. O objetivo principal deste estudo foi avaliar os efeitos de um programa de tratamento para dor lombar crônica baseado nos princípios da estabilidade segmentar. O objetivo secundário foi propor uma adaptaçáo do Perfil de Saúde de Nottingham, um instrumento para avaliar a qualidade de vida.

MÉTODOS: Trata-se de um estudo pré-experimental envolvendo 25 pacientes com dor lombar crônica, de ambos os gêneros com idade média 50,5 anos. Foram realizadas 16 sessóes de um programa de exercícios de estabilização segmentar, com frequência de duas vezes por semana durante dois meses. Os instrumentos de medida foram: a escala analógica visual, o questionário de Roland-Morris e duas versóes do Perfil de Saúde Nottingham traduzida e a modificada.

RESULTADOS: Ao final do tratamento todos os pacientes apresentaram melhora significativa nas variáveis controladas no estudo. A versão modificada do Perfil de Saúde Nottingham apresentou forte e significativa correlação com o da versão traduzida ( $\mathrm{r} 0,88)$ e com o nível de incapacidade funcional avaliado pelo questionário de Roland Morris (r 0,85).

CONCLUSÁO: O programa de tratamento proposto mostrouse benéfico para os pacientes envolvidos no estudo. A versão modificada do Perfil de Saúde Nottingham pode ser utilizada para avaliar a percepção da qualidade de vida direcionada especialmente para pacientes com dor lombar crônica.

Descritores: Capacidade funcional, Dor lombar crônica, Fisioterapia, Qualidade de vida.

\section{INTRODUCTION}

In industrialized countries, low back pain (LBP) incidence and prevalence are alarming. It is estimated that at least $70 \%$ to $89 \%$ of the population have or shall have this pain in some stage of life ${ }^{1,2}$.

It is a public health problem affecting people regardless of their social and economic class ${ }^{3,4}$.

In Brazil, approximately 10 million people become disabled by this disease ${ }^{5}$, which is considered the first 
reason for sickness allowance and the third reason for disability retirement ${ }^{6}$. Chronic LBP may be induced by inflammatory and degenerative diseases, cancer, congenital defects, muscle weakness, rheumatic predisposition, signs of spinal or intervertebral discs degeneration and others ${ }^{1}$. There are many possibilities to manage this disabling condition and physiotherapy has several techniques to minimize LBP, including acupuncture, hydrotherapy, electrotherapy and therapeutic exercises ${ }^{7-9}$. With all these interventions, physiotherapy aims at minimizing pain, improving functional capacity and quality of life (QL) giving patients a new alternative to treatment involving the whole impaired structure ${ }^{10,11}$. Among therapeutic exercise techniques, there is the concept of lumbar segmental stabilization (SS), characterized by low intensity isometrics and deep trunk muscles synchrony, aiming at stabilizing lumbar spine and at protecting its structure against excessive wear ${ }^{12}$.

SS technique is a modern treatment approach based on kinesiology, which acts directly on lower trunk muscles, specifically on spinal anterolateral and posterior stabilizers. Other two muscles working in synchrony are transverse of abdomen and diaphragm, able to increase intra-abdominal pressure. Diaphragm also controls and prevents organs displacement. Adequate recruitment of these muscles aims at improving biomechanical stability of the lumbar segment and at protecting joint structures such as discs and ligaments against excessive tension and injuries ${ }^{13,14}$.

So, this study aimed at evaluating the effects of a treatment schedule based on SS exercises associated to the Spine School, emphasizing aspects of pain, functional capacity and QL. This study also had as secondary objective the proposal of adaptation of a measurement tool for QL, the Nottingham Health Profile (NHP). Such tool is already translated into Portuguese and was the basis for the study of relevant population, that is, patients with chronic low back pain (CLBP).

\section{METHODS}

The first stage was an experimental study with therapeutic intervention (segmental stabilization associated to the Spine School) with pre and post-test measurements. The second stage was a descriptive correlation study using modified NHP versus NHP and Rolland Morris (RM). Participated in the study patients of the Basic Health Unit (BHU) of the Floresta district (Joinville, SC), with diagnosis of unspecific chronic low back pain.

Initially, 40 patients were sequentially screened from the BHU waiting list, making up a convenience sample. From these, 25 have met inclusion criteria, being 19 females and 6 males with mean age of $50.5 \pm 10.4$ years. Inclusion criteria were patients of both genders, aged $\geq 18$ years with diagnosis of idiopathic LBP for more than three months. Exclusion criteria were specific LBP (e.g., disc herniation, canal stenosis, postoperative period of tumors), and patients who attended to less than $75 \%$ of the treatment program.

A chart was used to record patients' personal and historical data. Then, specific measurement tools were used:

- Visual analog scale (VAS) was used for pain intensity. This tool is characterized by a numerical ordinal scale varying from zero to 10 , where zero means no pain, five is moderate pain and 10 means severe pain ${ }^{15}$;

- NHS, in its original translated and modified versions was used for self-perceptive evaluation of QL (Attachment 1) of patients with chronic low back pain. NHS is a questionnaire with 38 questions and its score may vary from zero (minimum) to 38 (maximum) being that $\mathrm{NO}$ will always score zero and YES will score $1^{16}$. In modified NHP applied in this study, four questions were included in a total of 42 questions regarding patients' perception of the QL. In presented items, score may vary from zero (minimum) to 84 (maximum). The answer $\mathrm{NO}$ is always scored zero, the answer SOMETIMES is scored 1 and the answer YES is scored 2.

In both translated and modified NHS the higher the score, the more severe the impairment of QL. Questionnaires evaluate the level of energy, pain, sleep, social interaction, physical skills and emotional reactions. Modified NHS includes four additional questions specific for pain, namely 7, 18, 20 and 30. Other questionnaire questions were maintained according to original NHS. This modified version was evaluated by three specialists experienced in managing patients with spinal pain, especially LBP ${ }^{17,18}$.

\section{Procedures}

After receiving all information about evaluation and management procedures, participants have signed the Free and Informed Consent Term (FICT).

During pre-test, selected patients were interviewed to collect their data by means of a history chart, including socio-demographic and clinical data; major complaint, pain evaluation (VAS), history of current, previous and family disease, associated diseases, use of drugs and lifestyle.

Data were collected in two moments: in the pre-test, before starting the treatment schedule, and in the posttest, always collected by BHU physiotherapist.

Deep muscles strengthening exercises are applied by means of isometric contractions of trunk muscles, requiring further recruitment of tonic fibers of the muscle system, located along the spine, thus maintaining good support in the upright position ${ }^{19,20}$. Muscle strengthening was developed according to continuous practice, recruiting an increasingly larger number of fibers due to static contraction ${ }^{21}$.

Selected physiotherapeutic intervention for patients was based on the SS technique. Along treatment, 11 exercises were performed, divided in three levels, according to patients' evolution. These levels were classified as easy, in a total of 7 exercises, moderate 2 and difficult also 2 . During 16 sessions (twice a week, lasting approximately 
60 minutes) therapeutic exercises were performed aimed at stretching ischiotibial muscles and paravertebral muscles. Both were performed twice lasting 30 second in the beginning of each session and twice lasting 30 seconds at the end of the session.

Then exercises based on SS were performed, with isometric strengthening: $1^{\text {st }}$ stage (first 6 sessions) with four easy exercises. In the $2^{\text {nd }}$ stage $\left(7^{\text {th }}\right.$ to $12^{\text {th }}$ session) all easy exercises were performed plus 2 moderate exercises. Finally, in the $3^{\text {rd }}$ stage $\left(13^{\text {th }}\right.$ to $16^{\text {th }}$ session), patients concluded with the 11 exercises, demanding abdominal, multifidus, erector spinae and transverse of abdomen muscles, including bridge, four supports and trunk elevation ${ }^{22,23}$. Symmetrically, 10 repetitions were performed and asymmetrically 5 repetitions. Posture was started with prolonged inspiration, maintaining concentration for 5 seconds. Exercise was ended with expiration and return to original position ${ }^{13,24}$.

\section{Statistical analysis}

The program GraphPad Prism $5^{\circ}$ was used for data tabulation and analysis. Descriptive statistics data were obtained, such as mean and standard deviation. To test differences between pre and post-test measurements, paired Student $t$ test was used with significance level of 95\% ( $\mathrm{p}<0.05)$. To observe the relationship among studied variables (Modified versus Translated NHP, RollandMorris questionnaire and VAS) Pearson Correlation Test was used with significance level of $95 \%(\mathrm{p}<0.05)$.

This study was approved by the Human Research Ethics Committee, Associação Educacional Luterana Bom Jesus/ IELUSC, number 427.648 .

\section{RESULTS}

There has been predominance of females (76\%). Eleven patients were active and regularly working and 14 were on medical leave and/or retired. Twenty patients were using drugs before treatment and 5 had no analgesic drug. After the treatment period, just two continued using regular drugs and 18 have interrupted or decreased their use.

Our results are shown in table 1 by means of descriptive statistical analysis and significance level between pre and post-test of all controlled variables.

Table 1 shows that all patients have improved in all measurements of this study.
Table 2 shows correlation analysis between modified NHP and other measurement tools used in the study.

Table 2. Correlation of modified Nottingham Health Profile versus other measurements of the study.

\begin{tabular}{lccc}
\hline MNHP & NHP & RM & VAS \\
\hline$r$ & $0.88^{\star}$ & $0.85^{\star}$ & $0.31^{*}$ \\
p value & $<0.0001$ & $<0.0001$ & 0.0296 \\
\hline
\end{tabular}

MNHP = Modified Nottingham Health Profile (0-84); NHP = Nottingham Health Profile (0-38); RM = Roland Morris (0-24); VAS = visual analog scale (0-10); *significant correlation coefficient $(p<0.05)$.

Table 2 shows that Modified NHP had good correlation with all other measurement tools of the study. Especially, there is very strong and positive correlation with translated NHP and RM. With VAS, correlation is weak, although significant.

Modified NHP is useful for the relevant population. The possibility of grading patients' answers in YES, SOMETIMES and NO, provides further sensitivity to the tool to evaluate quality self-perception of these patients. This version was evaluated and validated by three specialists, experienced in the clinical practice in spinal disorders. Unanimously, they considered it adequate to be applied to low back pain patients.

\section{DISCUSSION}

Participants of the study have shown significant improvement in all measurement tools used for variables control. According to details of study participants, it was observed higher incidence of females. This is compatible with other studies already carried out in Brazil ${ }^{1}$. This predominance might be explained by cultural issues involving female in home tasks and professional responsibilities, being more susceptible to chronic diseases and due to biomechanical differences as compared to males ${ }^{1,25,26}$.

In a randomized clinical trial by Korelo et al. ${ }^{14}$, with 12 sessions, patients improved pain already in the first SS treatment day and also during intervention, maintaining a stable level of pain. So, the intervention made that, at the end of treatment, no major VAS changes were found. However, there has been pain improvement. In our study, patients submitted to SS have improved according to VAS when pre and post-test evaluations were compared.

According to Sakamoto et al. $^{27}$, there has been pain and

Table 1. Descriptive statistics of studied variables

\begin{tabular}{|c|c|c|c|c|c|c|c|c|}
\hline & $\begin{array}{l}\text { VAS } \\
\text { Pre }\end{array}$ & $\begin{array}{l}\text { VAS } \\
\text { Post }\end{array}$ & $\begin{array}{l}\text { RM } \\
\text { Pre }\end{array}$ & $\begin{array}{c}\text { RM } \\
\text { Post }\end{array}$ & $\begin{array}{l}\text { NHP } \\
\text { Pre }\end{array}$ & $\begin{array}{l}\text { NHP } \\
\text { Post }\end{array}$ & $\begin{array}{l}\text { MNHP } \\
\text { Pre }\end{array}$ & $\begin{array}{c}\text { MNHP } \\
\text { Post }\end{array}$ \\
\hline Mean & 3 & 0.7 & 7.4 & 3.4 & 14 & 8,5 & 23 & 11 \\
\hline SD & 2.3 & 1 & 5.2 & 3.5 & 6.9 & 8,2 & 14 & 10 \\
\hline$p$ value & $<0.000$ & & $<0.000$ & & $<0.000$ & & $<0.000$ & \\
\hline
\end{tabular}

VAS = visual analog scale (0-10); RM = Rolland Morris (0-24); NHP = Nottingham Health Profile (0-38); MNHP = Modified Nottingham Health Profile (0-84); SD = standard deviation. 
functionality improvement in a group of 13 individuals (3 males and 10 females), submitted to SS exercises after 12 sessions performed three times a week. In the study by Pereira, Ferreira and Pereira ${ }^{28}$, sample was made up of 10 female patients submitted to 12 SS treatment sessions, twice a week, to manage pain and improve functional capacity of chronic low back pain individuals. These results are in line with our study, where 16 sessions were performed twice a week with 25 patients, being 19 females and 6 males. In our study, although with higher number of patients and a large part being made up of females, it was possible to observe improved pain in patients with CLBP, even with a mild difference in frequency of sessions.

As to QL aspects evaluation, it is known that it is impossible to accurately measure them, however it is important to collect information on how patients perceive their QL. So, a measurement tool such as NHP, which is a generic tool to evaluate $\mathrm{QL}$, might be useful ${ }^{29}$. Our study presents an adapted version for LBP patients. This NHP adaptation includes more answers options and also some specific questions to detect the influence of LBP on QL of this special population. In fact, LBP is a very common and in general disabling disorder. Negative effects of this disease are expressed by the strong relationship of incapacity level and negative perception of QL of patients ${ }^{30}$.

\section{CONCLUSION}

The program of exercises based on SS principles has resulted in significant benefits to involved patients. There has been pain, functional capacity and QL perception improvement. Proposed modification to NHP was sensitive to detect changes in QL perception of these patients. Specific questions about pain inserted in the tool and a change in answers range with regard to frequency of chronic LBP-induced changes might have contributed to good results found.

Attachment 1. Self-perceived evaluation of quality of life in chronic low back pain. Modified ${ }^{16}$

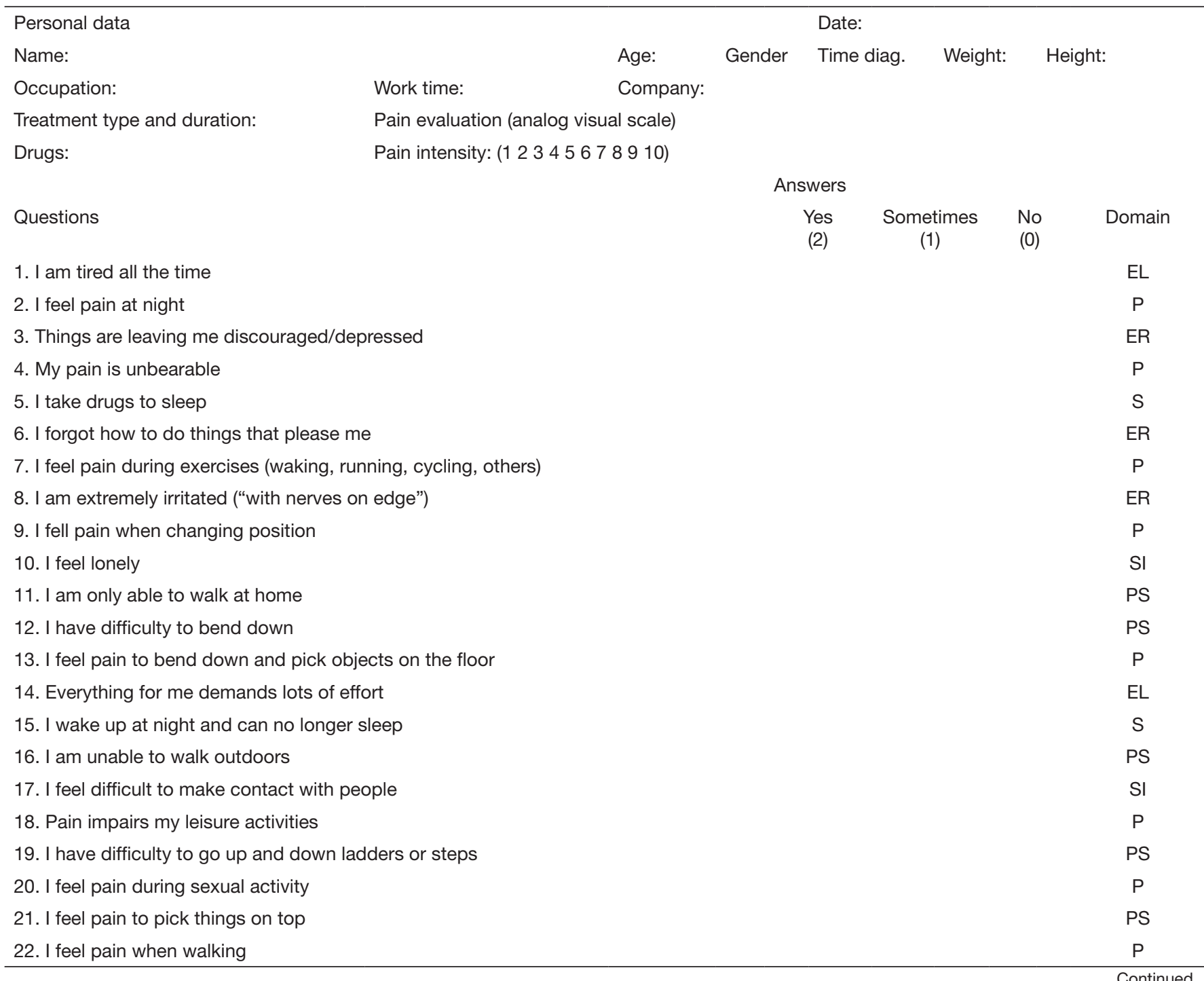


Attachment 1. Self-perceived evaluation of quality of life in chronic low back pain. Modified ${ }^{16}-$ continuation $^{-}$

23. Currently I lose temper very easily

24. I feel that there is no one close in whom to trust

25. I stay awake most part of the night

26. I feel as if I were losing control

27. I feel pain in the upright position

28. It is difficult to dress myself

29. I lose energy very easily

30. I feel pain when urinating or defecating

31. I have difficulty to remain standing up for a long time

32. I take a long time to get to sleep

33. I feel myself as a weight to other people

34. Concerns are keeping me awake at night

35. I feel that life is not worth living

36. I sleep badly at night

37. I have difficulty in relating to other people

38. I need help to walk outdoors (crunches, stick or someone supporting)

\section{REFERENCES}

1. Silva MC, Fassa AG, Valle NC. [Chronic low back pain in a Southern Brazilian adult population: prevalence and associated factors]. Cad Saude Publica. 2004;20(2):37785. Portuguese.

2. Arantes S, Ferreira C, Lobo S, Moutinho R, Correia J, Carvalho CJ. Lombalgias: a realidade na nova unidade de tratamento de dor. Rev Dor. 2007;15(3):22-7.

3. Caraviello EZ, Wasserstein S, Chamlian TR, Masiero D. Avaliaçấo da dor e função de pacientes com lombalgia tratados com um programa de Escola de Coluna. Acta Fisiatrica. 2005;12(1):11-4.

4. Volpato CP, Fernandes SW, Carvalho NA, Freitas DG. Exercícios de estabilizaçấo segmentar lombar na lombalgia: revisăo sistemática da literatura. Arq Med Hosp Fac Cienc Med Santa Casa São Paulo. 2012;57(1):35-40.

5. Sponchiado P, Carvalho AR. Descrição dos efeitos do protocolo "escola de coluna moderna” em portadores de lombalgia crônica. Fit Perf J. 2007;6(5):284-8.

6. Tavares Neto A, Faleiro TB, Moreira FD, Jambeiro JS, Schulz RS. Lombalgia na atividade policial militar: análise da prevalência, repercussōes laborativas e custo indireto. Rev Bahiana Saúde Pública. 2013;37(2):365-74.

7. Imamura ST, Kaziyama HH, Imamura M. Lombalgia. Rev Med. 2001;80(2):375-90.

8. Helfenstein Junior M, Goldenfum MA, Siena C. [Occupational low back pain]. Rev Assoc Med Bras. 2010;56(5):583-9. English, Portuguese.

9. Macedo CS, Briganó JU. Terapia manual e cinesioterapia na dor, incapacidade e qualidade de vida de indivíduos com lombalgia. Espaço Saúde. 2009;10(2):1-6.

10. Andrade SC, Araújo AG, Vilar MJ. "Escola de Coluna”: revisão histórica e sua aplicação na lombalgia crônica. Rev Bras Reumatol. 2005;45(4):224-8.

11. Freitas KP, Barros SS, Angelo RC, Uchôa PB. Lombalgia ocupacional e postura sentada: Efeitos da cinesioterapia laboral. Rev Dor. 2011;12(4):308-13.

12. Richardson CA, Jull GA. Muscle control-pain control. Watch exercises would you prescribe; Man Ther. 1995;1(1):2-10.

13. Santos RM, Freitas GD, Pinheiro IC, Vantina K, Gualberto H, Carvalho NA. Estabilização segmentar lombar- artigo de revisão. Med Reabil. 2011;30(1):14-7.

14. Korelo RIG, Ragasson CA, Lerner CE, Morais JC, Cossa JB, Krauczuk C. Efeitos de um programa cinesioterapeutico de grupo, aliado a escola de postura na lombalgia crônica. Rev Fisioter Mov. 2013;26(2):389-94.

15. Stefane T, Santos A, Marinovic A, Hortense P. Dor lombar crônica: intensidade de dor, incapacidade e qualidade de vida. Acta Paul Enferm. 2013;26(1):14-20.

16. Teixeira-Salmela LF, Magalhães Lde C, Souza AC, Lima Mde C, Lima RC, Goulart F.
[Adaptation of the Nottingham Health Profile: a simple measure to assess quality of life]. Cad Saude Publica. 2004;20(4):905-14. Portuguese.

17. Nusbaum L, Natour J, Ferraz MB, Goldenberg J. Translation, adaptation and validation of Roland-Morris questionnaire--Brazil Roland-Morris. Braz J Med Biol Res. 2001;34(2):203-10.

18. Mascarenhas MH, Santos SL. Avaliação da dor e da capacidade funcional em indivíduos com lombalgia crônica. J Health Sci Inst. 2011;29(3):205-8.

19. França RJ, Burke NT, Claret CD, Marques AP. Estabilização segmentar da coluna lombar nas lombalgias: uma revisão bibliográfica e um programa de exercícios. Rev Fisioter Pesq. 2008;15(2):200-6.

20. Ikedo F, Trevisan FA. Associaçáo entre lombalgia e deficiência de importantes grupos musculares posturais. Rev Bras Reumatol. 1998;38(6):321-6.

21. Ferreira MC, Penido H, Aun A, Ferreira P, Ferreira ML, Oliveira VC. Eficácia dos exercícios de controle motor na dor lombopélvica: uma revisão sistemática. Fisioter Pesq. 2009;16(4):374-9.

22. Gouveia KM, Gouveia EC. O músculo transverso abdominal e sua funçăo de estabilização da coluna lombar. Fisioter Mov. 2008;21(3):45-50.

23. Nogueira $\mathrm{CH}$, Navega TM. Influência da escola de postura na qualidade de vida, capacidade funcional, intensidade de dor e flexibilidade de trabalhadores administrativos. Rev Fisioter Pesq. 2011;18(4):353-8.

24. Steffenhagen AK. Manual da coluna: Mais de 100 exercícios para você viver sem dor $2^{\mathrm{a}}$ ed. Curitiba: Estética Artes Gráficas Ltda; 2004. 156p.

25. Hales TR, Sauter SL, Petterson MR, Fine LJ, Putz-Anderson V, Schleifer LR, et al. Musculoskeletal disorders among visual display terminal users in a telecommunications company. Ergonomics. 1994;37(10):103-21.

26. Almeida IC, Sá KN, Silva M, Batista A, Matos AM, Lessa Í. Prevalência de dor lombar crônica na população da cidade de Salvador. Rev Bras Ortop. 2008;43(3):96-102.

27. Sakamoto AC, Nicácio AS, Silva LA, Victória Júnior RC, Andrade IL, Nascimento LR. Efeito dos exercícios de estabilização na intensidade da dor e no desempenho funcional em indivíduos com lombalgia crônica. ConScientiae Saúde 2009;8(4):615-9.

28. Pereira NT, Ferreira LA, Pereira WM. Efetividade de exercícios de estabilizaçăo segmentar sobre a dor lombar crônica mecânico-postural. Fisioter Mov. 2010;23(4):605-14.

29. Atalay NS, Sahin F, Atalay A, Akkaya N. Comparison of efficacy of neural therapy and physical therapy in chronic low back pain. Afr J Tradit Complement Altern Med. 2013; 10(3):431-5.

30. Smeets R, Koke A, Lin CW, Ferreira M, Demoulin C. Measures of Function in Low Back Pain/Disorders. Arthritis Care \& Research. 2011; 63(S11): 158-73. 